\title{
A comparative study of knowledge, beliefs, and opportunities to learn afforded to physical science B.Ed students
}

\section{David Letloenyane}

School of Education Studies, University of the Free State, Bloemfontein, South Africa

LetloenyaneMD@ufs.ac.za

https://orcid.org/0000-0001-6493-9445

\section{Loyiso Jita}

Office of the Dean of Education, University of the Free State, Bloemfontein, South Africa

JitaLC@ufs.ac.za

https://orcid.org/0000-0001-6871-6820

(Received: 11 December 2019; accepted: 10 May 2021)

\section{Abstract}

Since large-scale studies show country and institutional differences in the preparation of B.Ed students, there is growing interest in the determination of the opportunities-to-learn afforded to them and the effects thereof in South African universities and elsewhere. There are, however, few studies that provide a contextually nuanced view of the effects of teacher education programmes on B.Ed students. This study therefore compares opportunities-to-learn afforded to physical science B.Ed students and their levels of competence that include knowledge and beliefs at four South African universities. Quantitative analysis reveals that some universities afforded these students more opportunities-to-learn in agreement with the nature of these universities. Furthermore, some opportunities-to-learn afforded to B.Ed students are provisionally related to measures of beliefs but they are not related to knowledge measures. Our findings suggest that while the B.Ed students seem to be afforded sufficient opportunities-to-learn at some universities, this does not readily translate into higher levels of competence.

Keywords: teacher preparation programmes, opportunities-to-learn, teacher knowledge, teacher beliefs, physical science B.Ed students

\section{Introduction}

International comparative assessments such as the Trends in International Mathematics and Science Study (TIMSS) have shown that South African learners lag behind those in other countries in terms of achievement in mathematics and science (Isdale et al., 2017; Reddy et 
al., 2016; Spaull, 2013). While there may be numerous reasons for this inadequate achievement, the literature suggests that the quality of pre-service teacher education may also be one of the contributing factors (Blomeke et al., 2012; Taylor, 2014; Tillotson \& Young, 2013). Therefore, we need to understand the effects of teacher education programmes on aspects of B.Ed students' competence i.e., their knowledge and beliefs.

The Teacher Education and Development Study: Learning to Teach Mathematics (TEDS-M) undertaken by Michigan State University under the aegis of the International Association for the Evaluation of Educational Achievement sought to fill this gap by using a sample of primary school B.Ed students to determine whether and, if so, how teacher education contributes to teacher competence (Schmidt et al., 2011). The TEDS-M study offered scholars the opportunity to determine the relationship between and among teacher knowledge, beliefs, and opportunity-to-learn across different countries.

In this study, following Blomeke and Kaizer (2014), description, opportunity-to-learn refers to all the experiences that are offered by the curriculum in a specific teacher education programme. We focus specifically on two categories of teacher knowledge-pedagogical content and content knowledge as described by Shulman (1986). Pedagogical content knowledge refers to ways of presenting content so that it is comprehensible to learners while content knowledge refers to the amount and organisation of subject matter that is held by an individual (Shulman, 1986). We also consider B.Ed students' beliefs about how they experienced aspects of their teacher education programme.

Initial analysis of the TEDS-M results indicated that there were significant differences in B.Ed students' background and the opportunities-to-learn that they were afforded during their training (Blomeke et al., 2012). Differences in the outcomes measures such as mathematics pedagogical content knowledge and mathematics content knowledge were also identified (Schmidt et al., 2011). Of importance to the present study is that the TEDS-M study's findings indicated that there are significant differences in opportunity-to-learn offered and the subsequent outcome measures between and among universities in the same country (Schmidt et al., 2011). Since this seems to be the case for mathematics teacher education in the United States, it remains to be seen if this is also the case for science teacher education in South Africa.

In our study, we compared opportunity-to-learn, beliefs, and test performance (knowledge) of the respondents from four universities in South Africa. This strategy allowed for the portrayal of similarities and differences in opportunity-to-learn that may influence B.Ed students' test performance and beliefs. We formulated two research questions:

- What are the possible similarities or differences between and among physical science final year B.Ed students' knowledge, beliefs, and opportunity-to-learn offered in selected teacher education programmes?

- What are possible relationships between and among the knowledge, beliefs, and opportunity-to-learn offered to physical science final year B.Ed students in selected teacher education programmes? 


\section{Literature}

\section{Opportunity-to-learn and the curriculum in teacher education programmes}

Researchers have commented on the nature of curriculum in higher education spaces globally and in South Africa. According to them, teacher education curricula can be considered to be sectoral/segmental which means that in its delivery it draws on knowledge from various fields of knowledge (Luckett, 2001; Muller, 2009). This can be seen clearly in the formulation of the Minimum Requirement for Teacher Education Qualification (MRTEQ) policy document. MRTEQ prescribes that B.Ed students be exposed to different types of knowledge including disciplinary, pedagogical, practical, situational, and foundational knowledge (DHET, 2015). The intention behind this integration of knowledge appears to expose B.Ed students to appropriate experiences for their chosen phase and learning area specialisation. Although the integration of knowledge areas seems desirable, researchers have observed that the integration of the types of knowledge as suggested by MRTEQ in practice is not automatic or easy to achieve (Hoban, 2005; Rusznyak, 2015). Hence, B.Ed students may find it challenging to see the bigger picture behind all the experiences afforded to them in their teacher education programmes.

Although teacher education programmes in South African universities use the same framework (MRTEQ) to prepare teachers, there will likely be differences in the implementation of the framework because of historical and cultural differences between and among various universities (Schmidt et al., 2011). It is therefore desirable to compare the manner in which various universities implement the relevant teacher education policies such as MRTEQ. The comparisons in terms of implementation allow for the determination of the kinds of opportunity-to-learn that likely lead to science teachers with adequate knowledge, skills, and desirable beliefs (Blomeke \& Kaiser, 2014). Furthermore, teachers are prepared at what are known in South Africa as traditional universities or at what are called universities of technology. The latter evolved from what were known as technikons and what separated them from traditional universities was that their curricula were designed to expose students to practical aspects of the work place; this was much less the case at traditional universities (Council on Higher Education, 2010). Our interest here was to determine if the universities involved in the study offer similar or varying opportunity-to-learn to their B.Ed students. In our view, the opportunity-to-learn offered by the universities represents the individual university's interpretation and implementation strategies of the MRTEQ policy document. We were also interested in determining if the opportunity-to-learn, as interpreted, and implemented, leads to higher levels of competence.

\section{Opportunities to learn and pre-service teacher outcomes}

Research regarding B.Ed students should, as one of its focus areas, investigate and explore the effects of different experiences offered by teacher education programmes on B.Ed students' beliefs and knowledge (Boyd et al., 2009; Koc, 2012; Roychoudhury \& Rice 2013; Tillotson \& Young, 2013). Unfortunately, a limited number of such investigations appear in 
the literature, and this will always call into question the so-called obvious link between teacher training and teacher quality. There are, however, a fair number of studies that have indicated the kinds of experiences or opportunity-to-learn that B.Ed students are afforded, and some studies have provided possible effects of the opportunity-to-learn on B.Ed students' outcomes that, in the context of this paper, include knowledge and beliefs (e.g., Ingvarson et al., 2007; Taylor, 2014; Tillotson \& Young, 2013). Other studies have suggested that there are relationships between B.Ed students' knowledge and beliefs (Mansour, 2009) with researchers having suggested that beliefs act as a filter for knowledge acquisition (Kutálková, 2017; Tondeur et al., 2016).

The impact of teacher knowledge domains as described by Shulman (1986) on teacher education outcomes that include teacher knowledge and beliefs, is probably one of the most studied relationships in the literature. Exposure to the categories of knowledge has been shown to affect the majority of the outcomes including B.Ed students' knowledge and beliefs (see Cetin et al., 2014; Macugay \& Bernardo, 2013; Santau et al., 2014; Tatar, 2015). Schmidt et al. (2011) found that there was a significant relationship between pre-service mathematics teachers' knowledge and the opportunity-to-learn knowledge. Opportunity-tolearn advanced topics in mathematics including calculus was found to be related to preservice mathematics teachers' scores on functions, algebra, data, and number geometry (Schmidt et al., 2011). Tanase and Wang (2010) showed that middle-grade B.Ed students' beliefs changed to an appreciation of learner-centred approaches after interactions with some courses that focussed on subject matter in their respective programmes.

An analysis of the curriculum for primary school B.Ed students in five case study universities in South Africa established that teacher education programmes are aimed primarily at preparing reflective practitioners (Taylor, 2014). Although Taylor (2014) noted that the practice of reflection was an essential part of teacher education, it was not immediately clear what kinds of experiences lead to reflective practitioners; this lends partial support to the notion that there is more talk of reflection than its actual practice in teacher education (Beauchamp, 2015).

In terms of teaching practice, Rusznyak and Bertram (2014) found that the teaching practice assessment criteria differed widely in quality, quantity, and context in teacher education programmes. On the one hand, numerous empirical studies have shown that teaching practice affects most of the outcomes of teacher education (e.g., Boyd et al., 2009; Ingvarson et al., 2007; Tillotson \& Young, 2013). On the other, Hancock and Gallard (2004) found that engaging in teaching practice left B.Ed students believing that learners learnt physical science better through lecturing and memorisation. These researchers observed that B.Ed students believed that learners lacked the motivation or skill to implement idealised science instruction in the classroom.

Coherence is also considered an important feature of teacher education programmes although the ingredients of a coherent programme are not consistent according to the literature (Grossman et al., 2008). Tatto (1996, p. 176) defined coherence as "shared understandings among faculty and in the manner in which opportunities to learn have been arranged 
(organizationally, logistically) to achieve a common goal." Nevertheless, some literature has shown that coherence helps shape B.Ed students' beliefs and practice (see Canrinus et al., 2017; Rogers, 2011). The latter reported that the lack of coherence manifests itself in B.Ed students who are uncertain about the type of teachers they are expected to be.

The reviewed literature indicates that opportunity-to-learn offered in teacher education programmes affects B.Ed students' outcomes and our study specifically sought to compare the opportunity-to-learn offered by various universities and to determine possible relationships between the opportunity-to-learn and B.Ed students' knowledge and beliefs. In this article, we also attempt to establish what these findings mean in the context of teacher education in South African higher education institutions.

\section{Methodology}

For this study, we employed a quantitative approach because quantitative analysis allowed for measurement and for statistical treatment of the data (Johnson \& Christensen, 2012). The approach further allowed for the assessment of the statistical relationships that could exist between B.Ed students' knowledge, beliefs, and the opportunity-to-learn that they are afforded in their teacher education programmes. We used non-experimental designs in the form of surveys and an achievement test to collect data. The use of surveys allowed for the collection of information such as opinions, attitudes, and beliefs of respondents and, following Creswell (2014), also for comparing or relating the data to a specific variable.

Four universities participated in the study that drew 112 respondents. Table 1 indicates whether respondents were from traditional universities or from universities of technology. The respondents were B.Ed physical science students who were in their final year of study. Final year students were chosen with the understanding that they would have developed most of the necessary competencies for teaching by that point. The students were randomly sampled, and approximately $70 \%$ of the students in the selected institutions participated in the study.

\section{Table 1}

Number of respondents per university

\begin{tabular}{|c|c|c|c|}
\hline & Type of university & $\begin{array}{c}\text { Number of } \\
\text { respondents }\end{array}$ & $\begin{array}{c}\text { Registered class } \\
\text { number }\end{array}$ \\
\hline U1 & Traditional University & 24 & 30 \\
\hline U2 & University of Technology & 33 & 41 \\
\hline U3 & University of Technology & 16 & 21 \\
\hline U4 & Traditional University & 39 & 54 \\
\hline \multicolumn{2}{|c|}{ Total Number of Respondents } & $\mathbf{1 1 2}$ & \\
\hline
\end{tabular}

B.Ed students' knowledge was assessed by means of an achievement test that was comprised of multiple-choice items that measured physical science B.Ed students' pedagogical content and content knowledge. The instrument was adopted from one used by Mahlomaholo et al. (2014) to assess teacher knowledge in one province in South Africa. The content knowledge 
(CK) measured was school-level physical science (18 items) and the pedagogical content knowledge (PCK) (6 items) was limited to 2 aspects of the construct that include misconceptions and the use of teaching strategies.

Teacher beliefs were measured by means of a Likert-scale survey. The instrument was adopted from the TEDS-M study as described in Tatto et al. (2008). The beliefs that were surveyed included those about (i) the nature of science (BLF1); (ii) learning science (BLF2); (iii) science achievement (BLF3); (iv) preparedness for teaching physical science (BLF4); and (v) programme effectiveness (BLF5).

The instrument for opportunity-to-learn was adopted from the TEDS-M study as described in Tatto et al. (2008). The instrument that was comprised of Likert scales and yes and no items measured the opportunity-to-learn tertiary-level physics and chemistry (OTL1), school-level physical science (OTL2), physical science education/pedagogy (OTL3), teaching through reflection on practice (OTL4), teaching through teaching practice (OTL5, OTL6, OTL7), and learning in a coherent teacher education programme (OTL8).

Data was collected in the first semester of 2017 when the B.Ed students were almost at the end of their training. The collected data was subjected to validity and reliability tests such as Cronbach's alpha test $(\alpha>0.66)$ to determine the internal and external consistency of the survey items (see Johnson \& Christensen, 2012). Rasch analysis was used to determine the achievement tests' ability to discriminate between respondents (reliability indices $>0.66$ ). In line with Linacre (2012), the two indices indicated that the instruments were sufficiently valid and reliable. Mean scores of the variables were calculated and all the other scores from various institutions were compared with the average score. The opportunity-to-learn data was compared and used to understand data on teacher knowledge and beliefs.

In total, 131 questionnaires were completed and returned. The first step was to ensure that the respondents were final-year B.Ed candidates. After scanning through the questionnaires, we discovered that 12 questionnaires had been completed by Post Graduate Certificate in Education (PGCE) candidates and therefore their data was not included in the final analysis. The second step was to look for questionnaires in which the respondents did not complete three or more pages. There were seven such cases and this data was excluded in the analysis.

Data was subjected to inferential statistics to determine if there were any statistically significant variations among the measured variables. Analysis of variance (ANOVA) and post-hoc tests were used to assess the differences between and among the four universities' data.

\section{Findings}

Data for the knowledge construct is presented first, followed by beliefs, while the opportunity-to-learn data is presented last. Data presented in the findings section addresses the first research question and responses to the first and second research questions are captured in the discussion section. 


\section{Knowledge construct mean scores}

Table 2

Content and Pedagogical Content knowledge mean scores of correct responses

\begin{tabular}{|c|c|c|c|c|c|c|}
\hline & & & \multicolumn{2}{c|}{ CK: 18 items } & \multicolumn{2}{c|}{ PCK: 6 items } \\
\hline University & $\begin{array}{c}\text { Type of } \\
\text { university }\end{array}$ & Sample & Mean & SD & Mean & SD \\
\hline $\mathbf{U 1}$ & $\begin{array}{c}\text { Traditional } \\
\text { University }\end{array}$ & 24 & 46.6 & 16.9 & 56.9 & 26.0 \\
\hline $\mathbf{U 2}$ & $\begin{array}{c}\text { University } \\
\text { of } \\
\text { Technology }\end{array}$ & 33 & 71.5 & 12.6 & 71.7 & 19.3 \\
\hline $\mathbf{U 3}$ & $\begin{array}{c}\text { University } \\
\text { of } \\
\text { Technology }\end{array}$ & 16 & 41.9 & 22.8 & 53.1 & 27.4 \\
\hline $\mathbf{U 4}$ & $\begin{array}{c}\text { Traditional } \\
\text { University }\end{array}$ & 39 & 43.0 & 17.3 & 52.1 & 21.0 \\
\hline \multicolumn{2}{|c|}{ Aggregate Mean } & \multicolumn{2}{|c|}{52.0} & \multicolumn{2}{|c|}{59.1} \\
\hline
\end{tabular}

The content and pedagogical content knowledge mean scores in Table 2 show that the percentages of correct responses differ across the four universities. Data indicates that respondents from U3 (41.9) have the lowest mean score followed by U4 (43.0) and U1 (46.6) with U2 (71.5) having the highest mean score. Pedagogical content knowledge mean scores reveal that U4 (52.1) respondents have the lowest mean score followed by U3 (53.1) and U1 (56.9 with U2 (71.7) respondents having the highest mean score for pedagogical content knowledge. Data also reveals that only U2's content and pedagogical content knowledge mean scores are above the aggregated mean scores.

Table 3

Post-hoc tests for CK and PCK

\begin{tabular}{|c|c|c|c|}
\hline Variable & U_Num & U_Num & Sig. \\
\hline \multirow{4}{*}{ CK } & U1 & $\begin{array}{l}\mathrm{U} 2 \\
\mathrm{U} 3 \\
\mathrm{U} 4\end{array}$ & $\begin{array}{l}.000 \\
.850 \\
.882\end{array}$ \\
\hline & U2 & $\begin{array}{l}\text { U1 } \\
\text { U3 } \\
\text { U4 }\end{array}$ & $\begin{array}{l}.000 \\
.000 \\
.000 \\
\end{array}$ \\
\hline & U3 & $\begin{array}{l}\mathrm{U} 1 \\
\mathrm{U} 2 \\
\mathrm{U} 4\end{array}$ & $\begin{array}{l}.850 \\
.000 \\
.995\end{array}$ \\
\hline & U4 & $\begin{array}{l}\mathrm{U} 1 \\
\mathrm{U} 2 \\
\mathrm{U} 3\end{array}$ & $\begin{array}{l}.882 \\
.000 \\
.995\end{array}$ \\
\hline
\end{tabular}

\begin{tabular}{|c|c|c|c|}
\hline Variable & U_Num & U_Num & Sig. \\
\hline \multirow{4}{*}{ PCK } & U1 & $\begin{array}{l}\mathrm{U} 2 \\
\mathrm{U} 3 \\
\mathrm{U} 4\end{array}$ & $\begin{array}{l}.098 \\
.933 \\
.800\end{array}$ \\
\hline & U2 & $\begin{array}{l}\text { U1 } \\
\text { U3 } \\
\text { U4 }\end{array}$ & $\begin{array}{l}.098 \\
.041 \\
.002\end{array}$ \\
\hline & U3 & $\begin{array}{l}\text { U1 } \\
\text { U2 } \\
\text { U4 }\end{array}$ & $\begin{array}{l}.933 \\
.041 \\
.999\end{array}$ \\
\hline & $\mathrm{U} 4$ & $\begin{array}{l}\mathrm{U} 1 \\
\mathrm{U} 2 \\
\mathrm{U} 3\end{array}$ & $\begin{array}{l}.800 \\
.002 \\
.999\end{array}$ \\
\hline
\end{tabular}

ANOVA test statistics for content knowledge indicates that the universities' mean content knowledge scores are not statistically equivalent $(\mathrm{F}=22.58, \mathrm{p}=0.00)$. The Games-Howell post-hoc test in Table 3, which is used when equal variances are not assumed, indicates that U2 (71.5) mean scores are not statistically significantly equivalent to U1 (46.6), U3 (41.9), and U4 (43.0) mean scores. Furthermore, the post-hoc test revealed that U1, U3, and U4 mean scores are statistically equivalent. ANOVA test statistics for pedagogical content knowledge further indicate that the universities' mean pedagogical content knowledge scores 
are not statistically equivalent $(\mathrm{F}=5.01, \mathrm{p}=0.00)$. Tukey's post-hoc test in Table 3 that is used when equal variances are assumed, indicates that U2 (71.7) and U1 (56.9) mean scores are in one subset and U1 (56.9), U3 (53.1) and U4 (52.1) are in another.

In summary, the data indicates that with the exception of U2, the other universities' mean scores on content knowledge are below a mean score of 50. This suggests that there may be gaps in the B.Ed students' content knowledge from the said universities if we assume that a mean score of 50 represents adequate achievement. The situation is quite different for pedagogical content knowledge where all the universities' scores are above a mean score of 50 , suggesting that the B.Ed students may have adequate knowledge of physical science teaching strategies and diagnosis and correction of learner misconceptions.

\section{B.Ed students' beliefs constructs}

B.Ed students' beliefs were measured using Likert-scale items. The Likert-scale items for B.Ed students' beliefs were coded using the six responses which were 1: strongly disagree; 2 : disagree; 3: slightly disagree; 4: slightly agree; 5: agree; and 6: strongly agree. Only the Likert scale on teacher preparedness for teaching physical science (BLF4) was coded 1: Not at all; 2: A minor extent; 3: A modest extent; and 4: A major extent. Similar to the TEDS-M study reasoning, only respondents who chose agree and strongly agree (5 and 6 ) options were considered to be in agreement with the item and the rest, including slightly agree (3), were considered as not being in agreement with the item. For the teacher preparedness Likert scale, only respondents who chose option 4 were considered to be in agreement with the item. The descriptions above are used in the data presentations that follow and the mean score of respondents who agree with the statements are provided.

Table 4

Beliefs mean scores of universities

\begin{tabular}{|c|c|c|c|c|c|c|c|}
\hline \multirow[b]{2}{*}{ University } & \multirow[b]{2}{*}{$\begin{array}{c}\text { Type of } \\
\text { university }\end{array}$} & \multirow[b]{2}{*}{ Sample } & \multicolumn{5}{|c|}{ Beliefs mean scores (Number of items) } \\
\hline & & & $\begin{array}{l}\text { BLF1 } \\
\text { (6) }\end{array}$ & $\begin{array}{c}\text { BLF2 } \\
\text { (6) }\end{array}$ & $\begin{array}{c}\text { BLF3 } \\
\text { (6) }\end{array}$ & $\begin{array}{c}\text { BLF4 } \\
\text { (10) }\end{array}$ & $\begin{array}{c}\text { BLF5 } \\
\text { (6) }\end{array}$ \\
\hline U1 & $\begin{array}{l}\text { Traditional } \\
\text { University }\end{array}$ & 24 & 8.3 & 33.3 & 62.5 & 33.3 & 37.5 \\
\hline U2 & $\begin{array}{l}\text { University of } \\
\text { Technology }\end{array}$ & 33 & 97 & 97 & 100 & 66.7 & 100 \\
\hline U3 & $\begin{array}{l}\text { University of } \\
\text { Technology }\end{array}$ & 16 & 31.3 & 56.3 & 43.8 & 75 & 93.8 \\
\hline U4 & $\begin{array}{l}\text { Traditional } \\
\text { University }\end{array}$ & 39 & 12.8 & 53.8 & 46.2 & 51.3 & 66.7 \\
\hline \multicolumn{3}{|c|}{ Aggregate Mean } & 52.0 & 17.3 & 39.3 & 62.5 & 65.2 \\
\hline
\end{tabular}

Table 4 presents B.Ed students' frequencies of desirable beliefs. Data indicates that for beliefs about the nature of physical science (BLF1), beliefs about learning physical science (BLF2), and beliefs about programme effectiveness (BLF5), U1 has the lowest mean scores, followed by U4 and U3 while U2 has the highest mean scores. On average, U2 has the highest mean scores for all the beliefs variables while U1 has the lowest mean scores. Furthermore, U2 is the only university for which all the mean scores are above the aggregated mean score. 
Table 5

Post-hoc test for the belief constructs' mean scores

\begin{tabular}{|c|c|c|c|}
\hline Variable & U_Num & U_Num & Sig. \\
\hline \multirow{12}{*}{ BLF1 } & \multirow{3}{*}{ U1 } & U2 & .000 \\
\hline & & U3 & .368 \\
\hline & & U4 & .985 \\
\hline & \multirow{3}{*}{$\mathrm{U} 2$} & U1 & .000 \\
\hline & & U3 & .000 \\
\hline & & $\mathrm{U} 4$ & .000 \\
\hline & \multirow{3}{*}{ U3 } & U1 & .368 \\
\hline & & $\mathrm{U} 2$ & .000 \\
\hline & & $\mathrm{U} 4$ & .463 \\
\hline & \multirow{3}{*}{ U4 } & U1 & .985 \\
\hline & & U2 & .000 \\
\hline & & U3 & .463 \\
\hline
\end{tabular}

\begin{tabular}{|c|c|c|c|}
\hline Variable & U_Num & U_Num & Sig. \\
\hline \multirow{7}{*}{ BLF2 } & \multirow{4}{*}{ U1 } & U2 & .000 \\
& & U3 & .023 \\
& \multirow{4}{*}{ U2 } & U1 & .525 \\
\cline { 2 - 4 } & & U3 & .000 \\
& & U4 & .004 \\
& \multirow{2}{*}{ U3 } & U1 & .000 \\
\cline { 2 - 4 } & & U2 & .023 \\
& & U4 & .206 \\
\cline { 2 - 4 } & \multirow{2}{*}{ U4 } & U1 & .525 \\
& & U2 & .000 \\
& & U3 & .206 \\
\hline
\end{tabular}

\begin{tabular}{|c|c|c|c|}
\hline Variable & U_Num & U_Num & Sig. \\
\hline \multirow{12}{*}{ BLF3 } & \multirow{3}{*}{ U1 } & U2 & .000 \\
\hline & & U3 & 1.000 \\
\hline & & U4 & .969 \\
\hline & \multirow{3}{*}{ U2 } & U1 & .000 \\
\hline & & U3 & .000 \\
\hline & & U4 & .000 \\
\hline & \multirow{3}{*}{ U3 } & U1 & 1.000 \\
\hline & & U2 & .000 \\
\hline & & U4 & .993 \\
\hline & \multirow{3}{*}{ U4 } & U1 & .969 \\
\hline & & U2 & .000 \\
\hline & & U3 & .993 \\
\hline
\end{tabular}

\begin{tabular}{|c|c|c|c|}
\hline Variable & U_Num & U_Num & Sig. \\
\hline \multirow{7}{*}{ BLF4 } & \multirow{4}{*}{ U1 } & U2 & .002 \\
& & U3 & .016 \\
& & U4 & .111 \\
\cline { 2 - 4 } & \multirow{2}{*}{$\mathrm{U} 2$} & $\mathrm{U} 1$ & .002 \\
& & $\mathrm{U} 3$ & 1.000 \\
& \multirow{3}{*}{$\mathrm{U} 3$} & $\mathrm{U} 4$ & .340 \\
\cline { 2 - 4 } & & $\mathrm{U} 2$ & .016 \\
& & $\mathrm{U} 4$ & .564 \\
\cline { 2 - 4 } & \multirow{3}{*}{$\mathrm{U} 4$} & $\mathrm{U} 1$ & .111 \\
& & $\mathrm{U} 2$ & .340 \\
& & $\mathrm{U} 3$ & .564 \\
\hline
\end{tabular}

\begin{tabular}{|c|c|c|c|}
\hline Variable & U_Num & U_Num & Sig. \\
\hline \multirow{12}{*}{ BLF5 } & \multirow{3}{*}{ U1 } & U2 & .000 \\
\hline & & U3 & .006 \\
\hline & & U4 & .132 \\
\hline & \multirow{3}{*}{ U2 } & U1 & .000 \\
\hline & & U3 & .814 \\
\hline & & U4 & .007 \\
\hline & \multirow{3}{*}{ U3 } & U1 & .006 \\
\hline & & U2 & .814 \\
\hline & & U4 & .319 \\
\hline & \multirow{3}{*}{ U4 } & U1 & .132 \\
\hline & & U2 & .007 \\
\hline & & U3 & .319 \\
\hline
\end{tabular}

ANOVA test statistics for beliefs' mean scores indicates that the universities' mean scores are not significantly equivalent for all the beliefs variables $(\mathrm{p}<0.05)$. The Games-Howell post-hoc test in Table 5 indicates that for beliefs about the nature of physical science (BLF1), beliefs about learning physical science (BLF2), and beliefs about physical science achievement (BLF3), U2 mean scores are not statistically significantly equivalent to U1, U3, and U4 mean scores. Furthermore, the post-hoc test shows that U1, U3, and U4 mean scores are statistically significantly equivalent. There are no clear trends in terms of the universities scores for beliefs about preparedness for teaching physical science (BLF4) and beliefs about programme effectiveness (BLF5).

\section{Opportunity to learn in teacher education programmes}

Opportunity-to-learn scales consist of opportunity-to-learn tertiary-level physics and chemistry (OTL1), school physical science (OTL2), physical science pedagogy (OTL3), through reflection (OTL4), through practicum (OTL5, OTL6 and OTL7) and in a coherent 
programme (OTL8). The scales in the opportunity-to-learn construct are measured using Likert-scale items except the opportunities-to-learn physics, chemistry, and physical science that are assessed using Yes/No options.

Table 6

Opportunity to learn mean scores of universities

\begin{tabular}{|c|c|c|c|c|c|c|c|c|c|c|}
\hline & & & \multicolumn{8}{|c|}{ Opportunity to learn mean scores (Number of items measured) } \\
\hline University & $\begin{array}{c}\text { Type of } \\
\text { university }\end{array}$ & Sample & $\begin{array}{c}\text { OTL1 } \\
(40)\end{array}$ & $\begin{array}{c}\text { OTL2 } \\
\text { (21) }\end{array}$ & $\begin{array}{c}\text { OTL3 } \\
(10)\end{array}$ & $\begin{array}{c}\text { OTL4 } \\
(10)\end{array}$ & $\begin{array}{l}\text { OTL5 } \\
\text { (1) }\end{array}$ & 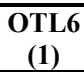 & $\begin{array}{c}\text { OTL7 } \\
\text { (8) }\end{array}$ & $\begin{array}{c}\text { OTL8 } \\
\text { (6) }\end{array}$ \\
\hline $\mathbf{U} 1$ & $\begin{array}{l}\text { Traditional } \\
\text { University }\end{array}$ & 24 & 0.75 & 0.95 & 2.44 & 2.63 & 2.60 & 2.75 & 2.13 & 2.77 \\
\hline $\mathbf{U} 2$ & $\begin{array}{c}\text { University of } \\
\text { Technology }\end{array}$ & 33 & 0.93 & 0.97 & 3.22 & 3.12 & 3.39 & 3.36 & 3.24 & 3.56 \\
\hline $\mathbf{U 3}$ & $\begin{array}{c}\text { University of } \\
\text { Technology }\end{array}$ & 16 & 0.93 & 0.92 & 3.28 & 3.50 & 3.47 & 3.50 & 3.25 & 3.72 \\
\hline $\mathbf{U} 4$ & $\begin{array}{l}\text { Traditional } \\
\text { University }\end{array}$ & 39 & 0.81 & 0.84 & 2.79 & 2.77 & 2.79 & 2.87 & 2.51 & 2.96 \\
\hline \multicolumn{3}{|c|}{ Aggregate Mean } & 52.0 & 17.3 & 0.85 & 0.91 & 2.91 & 2.95 & 3.03 & 3.08 \\
\hline
\end{tabular}

Table 6 presents the mean opportunity-to-learn scores for each university. Data indicates that for opportunity-to-learn physical science pedagogy (OTL3), through reflection (OTL4), through practicum (OTL5, OTL6 and OTL7) and in a coherent programme (OTL8), U1 has the lowest mean scores, followed by U4 and U2 while U3 has the highest mean scores. Opportunity-to-learn tertiary-level physics and chemistry (OTL1) displays a similar trend although $\mathrm{U} 2$ and $\mathrm{U} 3$ have similar scores.

Table 7

Post-hoc test for the opportunity to learn mean scores

\begin{tabular}{|c|c|c|c|}
\hline Variable & U_Num & U_Num & Sig. \\
\hline \multirow{12}{*}{ OTL2 } & \multirow{3}{*}{ U1 } & U2 & .001 \\
\hline & & U3 & .010 \\
\hline & & U4 & .641 \\
\hline & \multirow{3}{*}{ U2 } & U1 & .001 \\
\hline & & U3 & 1.000 \\
\hline & & $\mathrm{U} 4$ & . 011 \\
\hline & \multirow{3}{*}{ U3 } & U1 & .010 \\
\hline & & U2 & 1.000 \\
\hline & & U4 & .075 \\
\hline & \multirow{3}{*}{ U4 } & U1 & .641 \\
\hline & & U2 & .011 \\
\hline & & U3 & .075 \\
\hline
\end{tabular}

\begin{tabular}{|c|c|c|c|}
\hline Variable & U_Num & U_Num & Sig. \\
\hline \multirow{7}{*}{ OTL3 } & \multirow{4}{*}{ U1 } & U2 & .000 \\
& & U3 & .000 \\
& & U4 & .113 \\
\cline { 2 - 4 } & \multirow{2}{*}{ U2 } & U1 & .000 \\
& & U3 & .984 \\
& \multirow{4}{*}{ U3 } & U1 & .020 \\
\hline & & U2 & .000 \\
& & U4 & .084 \\
\cline { 2 - 4 } & \multirow{4}{*}{ U4 } & U1 & .113 \\
& & U2 & .020 \\
& & U3 & .037 \\
\hline
\end{tabular}

\begin{tabular}{|c|c|c|c|}
\hline Variable & U_Num & U_Num & Sig. \\
\hline \multirow{7}{*}{} & \multirow{4}{*}{ U1 } & U2 & .011 \\
& & U3 & .004 \\
& & U4 & .472 \\
\cline { 2 - 4 } & \multirow{4}{*}{ UT2 } & U1 & .011 \\
& & U3 & .819 \\
\cline { 2 - 4 } & \multirow{4}{*}{ U3 } & U1 & .192 \\
\hline & & U2 & .804 \\
& & U4 & .067 \\
\cline { 2 - 4 } & \multirow{4}{*}{ U4 } & U1 & .472 \\
& & U2 & .192 \\
& & U3 & .067 \\
\hline
\end{tabular}

\begin{tabular}{|c|c|c|c|}
\hline Variable & U_Num & U_Num & Sig. \\
\hline \multirow{7}{*}{} & \multirow{4}{*}{ U1 } & U2 & .099 \\
& & U3 & .091 \\
& & U4 & .964 \\
\cline { 2 - 4 } & \multirow{4}{*}{ U2 } & U1 & .099 \\
& & U3 & .969 \\
\cline { 2 - 4 } & \multirow{4}{*}{ U3 } & U1 & .155 \\
\hline & & U2 & .091 \\
& & U4 & .144 \\
\cline { 2 - 4 } & \multirow{3}{*}{ U4 } & U1 & .964 \\
& & U2 & .155 \\
& & U3 & .144 \\
\hline
\end{tabular}




\begin{tabular}{|c|c|c|c|}
\hline Variable & U_Num & U_Num & Sig. \\
\hline \multirow{12}{*}{ OTL6 } & \multirow{3}{*}{ U1 } & U2 & .000 \\
\hline & & U3 & .002 \\
\hline & & U4 & .398 \\
\hline & \multirow{3}{*}{ U2 } & U1 & .000 \\
\hline & & U3 & 1.000 \\
\hline & & U4 & .008 \\
\hline & \multirow{3}{*}{ U3 } & U1 & .002 \\
\hline & & U2 & 1.000 \\
\hline & & U4 & .049 \\
\hline & \multirow{3}{*}{ U4 } & U1 & .398 \\
\hline & & U2 & .008 \\
\hline & & U3 & .049 \\
\hline
\end{tabular}

\begin{tabular}{|c|c|c|c|}
\hline Variable & U_Num & U_Num & Sig. \\
\hline \multirow{6}{*}{} & \multirow{4}{*}{ U1 } & U2 & .000 \\
& & U3 & .000 \\
& & U4 & .454 \\
\cline { 2 - 4 } & \multirow{4}{*}{ UT2 } & U1 & .000 \\
& & U3 & .905 \\
\cline { 2 - 4 } & \multirow{4}{*}{ U3 } & U4 & .000 \\
\hline & & U2 & .000 \\
& & U4 & .905 \\
\cline { 2 - 4 } & \multirow{4}{*}{ U4 } & U1 & .454 \\
& & U2 & .000 \\
& & U3 & .009 \\
\hline
\end{tabular}

\begin{tabular}{|c|c|c|c|}
\hline Variable & U_Num & U_Num & Sig. \\
\hline \multirow{12}{*}{ OTL8 } & \multirow{3}{*}{ U1 } & $\overline{\mathrm{U} 2}$ & .001 \\
\hline & & U3 & .000 \\
\hline & & U4 & .554 \\
\hline & \multirow{3}{*}{ U2 } & U1 & .001 \\
\hline & & U3 & .704 \\
\hline & & U4 & .012 \\
\hline & \multirow{3}{*}{ U3 } & U1 & .000 \\
\hline & & U2 & .704 \\
\hline & & U4 & .003 \\
\hline & \multirow{3}{*}{ U4 } & U1 & .554 \\
\hline & & U2 & .012 \\
\hline & & U3 & .003 \\
\hline
\end{tabular}

ANOVA test statistics for opportunity-to-learn mean scores indicates that all the universities' opportunity-to-learn mean scores differ significantly with the exception of opportunity-tolearn school physical science (OTL2) $(\mathrm{p}=0.06)$ and therefore, a post-hoc analysis was not done for this opportunity-to-learn. The post-hoc tests in Table 7 indicate that in most cases, $\mathrm{U} 2$ and U3 opportunity-to-learn mean scores are not statistically significantly equivalent to $\mathrm{U} 1$ and $\mathrm{U} 4$ scores. The post-hoc test further shows that $\mathrm{U} 2$ and $\mathrm{U} 3$ scale scores are statistically significantly equivalent as well as U1 and U4. The exceptions are opportunity-tolearn through reflection (OTL4) and through practicum (OTL5) where data for OTL5 indicates that the mean scores for the universities are statistically equivalent.

In summary, respondents from U3 report that they are afforded the highest number of opportunities-to-learn followed by respondents from $\mathrm{U} 2$ and $\mathrm{U} 4$ while respondents from $\mathrm{U} 1$ report the lowest opportunity-to-learn mean score on average. ANOVA and post hoc tests reveal that $\mathrm{U} 2$ and $\mathrm{U} 3$ mean scores are statistically equivalent and that $\mathrm{U} 4$ and $\mathrm{U} 1$ scores are statistically equivalent. Furthermore, the ANOVA and post hoc tests reveal that the U2 and $\mathrm{U} 3$ mean scores are not statistically equivalent to U1 and U4 scores.

\section{Discussion of the findings}

In this study, we sought to compare the opportunity-to-learn, beliefs, and knowledge of the participating universities in order to portray variations, if any, and the possible effects of the variations of opportunity-to-learn on B.Ed students' knowledge and beliefs.

Data indicates that there are statistical differences between the universities' data in all the variables tested with the exception of opportunity-to-learn school-level physical science 
(OTL2: $p>0.05$ ). The data therefore indicates that there are variations between and among the universities' knowledge, beliefs, and opportunity-to-learn afforded to B.Ed students, similar to Schmidt et al.'s (2011) findings. The statistical equivalence of the universities' opportunity-to-learn school level physical science (OTL2) mean scores (see Table 7) may be because a significant portion of the content of tertiary level physics and chemistry courses for a B.Ed qualification contains topics that form part of the school-level physical science curriculum. The similarities may be the reason why most respondents indicated that they were afforded sufficient opportunity-to-learn school-level physical science topics in their respective programmes and, therefore, this may account for the statistical equivalence in the universities' mean scores.

\section{Table 8}

Mean scores of knowledge, beliefs and opportunity to learn

\begin{tabular}{|l|l|l|l|l|l|l|l|l|l|l|l|l|l|l|l|}
\hline $\begin{array}{l}\text { Univ } \\
\text { ersit } \\
\mathbf{y}\end{array}$ & $\mathbf{C K}$ & $\mathbf{P C K}$ & $\begin{array}{l}\text { BLF } \\
\mathbf{1}\end{array}$ & $\begin{array}{l}\text { BLF } \\
\mathbf{2}\end{array}$ & $\begin{array}{l}\mathbf{3} \\
\mathbf{3}\end{array}$ & $\begin{array}{l}\mathbf{B L F} \\
\mathbf{4}\end{array}$ & $\begin{array}{l}\text { BLF } \\
\mathbf{5}\end{array}$ & $\begin{array}{l}\text { OTL } \\
\mathbf{1}\end{array}$ & $\begin{array}{l}\text { OTL } \\
\mathbf{2}\end{array}$ & $\begin{array}{l}\text { OTL } \\
\mathbf{3}\end{array}$ & $\begin{array}{l}\text { OTL } \\
\mathbf{4}\end{array}$ & $\begin{array}{l}\text { OTL } \\
\mathbf{5}\end{array}$ & $\begin{array}{l}\text { OTL } \\
\mathbf{6}\end{array}$ & $\begin{array}{l}\text { OTL } \\
\mathbf{7}\end{array}$ & $\begin{array}{l}\text { OTL } \\
\mathbf{8}\end{array}$ \\
\hline $\mathbf{U 1}$ & 46,6 & 56,9 & 8,3 & 33,3 & 62,5 & 33,3 & 37,5 & 0,75 & 0,95 & 2,44 & 2,63 & 2,60 & 2,75 & 2,13 & 2,77 \\
\hline U2 & 71,5 & 71,7 & 97,0 & 97,0 & 100 & 66,7 & 100 & 0,93 & 0,97 & 3,22 & 3,12 & 3,39 & 3,36 & 3,24 & 3,56 \\
\hline U3 & 41,9 & 53,1 & 31,3 & 56,3 & 43,8 & 75,0 & 93,8 & 0,93 & 0,92 & 3,28 & 3,50 & 3,47 & 3,50 & 3,25 & 3,72 \\
\hline U4 & 43,0 & 52,1 & 12,8 & 53,8 & 46,2 & 51,3 & 66,7 & 0,81 & 0,84 & 2,79 & 2,77 & 2,79 & 2,87 & 2,51 & 2,96 \\
\hline Ave & 52,0 & 59,1 & 39,3 & 62,5 & 65,2 & 55,4 & 73,2 & 0,85 & 0,91 & 2,91 & 2,95 & 3,03 & 3,08 & 2,75 & 3,2 \\
\hline
\end{tabular}

Table 8 presents the three constructs' data in one table for comparative purposes and this strategy assists in responding to the second research question. Initial analysis of the universities' scores does not suggest any clear trends (directly or inversely proportional) in the universities' mean scores. For example, U3's opportunity-to-learn mean scores are, on average, higher than any other universities' score but the same university's beliefs and knowledge mean scores are not necessarily the highest. Similarly, U1 has, on average, the lowest opportunity-to-learn mean scores, but the same university's content (CK) and pedagogical content (PCK) knowledge mean scores are higher than U4 mean scores, although U4's opportunity-to-learn mean scores are, on average, higher than U1's opportunity-to-learn mean scores. While the literature suggested that some opportunities-to-learn are associated with improved B.Ed students' outcomes (e.g. Canrinus et al., 2017; Tillotson \& Young, 2013), given findings of the present study, we suggest that affording B.Ed students more opportunity-to-learn may not always translate into improved knowledge and desirable beliefs. The possible explanation may be that, individually, the opportunity-to-learn is associated with improved B.Ed students' outcomes but the improvements may be diminished by the average effect of all the opportunity-to-learn surveyed in this study.

The post-hoc tests reveal interesting results in terms of opportunity-to-learn mean scores. Games-Howell post-hoc tests illustrate that U2 mean scores are statistically equivalent to U3's scores $(p>0.05)$ in all the opportunity-to-learn variables except the opportunity-to-learn through reflection (OTL4). The post-hoc test also indicates that U2 and U3 mean scores are not statistically equivalent to U1 and U4 mean scores. Although the universities cannot be 
categorised exclusively into two subsets for opportunity-to-learn through reflection (OTL4) variable, U2 and U3, and U1 and U4 are nonetheless two of the subsets as suggested by the Games-Howell post-hoc test.

Data suggests that the universities may be divided into two groups, with U1 and U4 in one group (Group A) and U2 and U3 in Group B. Table 8 and the post-hoc tests indicate that the opportunity-to-learn mean scores for $U 1$ are equivalent to scores for $U 4$, and the same is true for data for U2 and U3. Furthermore, group B's opportunity-to-learn mean scores are statistically significantly higher than group A's mean scores.

The interesting observation about the findings is that group B represents universities of technology while group A represents traditional universities. This observation may be explained partially by the amount of time reserved for teaching practice in traditional universities and universities of technology. For example, one of the traditional universities reserved 23 weeks spread approximately evenly over the B.Ed students' 4 years of training for teaching practice (approximately 6 weeks per academic year). However, one of the universities of technology reserved significantly more time for teaching practice; in the first 3 years, students were allocated approximately 6 weeks of teaching practice time in each year and, additionally, they were expected to spend the first 6 months of their final year of training in schools. This allocation of teaching practice time provides support for the notion that universities of technology expose their B.Ed students to significantly more practical aspects of teaching than their traditional university counterparts do. Taylor (2014) also lamented that teaching practice time varies considerably between the institutions, but our study findings seem to suggest that the time for teaching practice may vary according to the type of institution. Furthermore, traditional universities expected their B.Ed students to have passed second year physics and chemistry as a minimum requirement while the universities of technology required their B.Ed students to have passed third year physics and chemistry. In terms of the higher education landscape in South Africa, the data suggests that the interpretations and implementation of the MRTEQ policy differs somewhat between the two types of universities. Even though the universities are guided by the same policy, the nature of the universities seems to affect their interpretation of this policy to such an extent that the curricula of universities of technology seem to afford more opportunity-to-learn to their B.Ed students than do their traditional university counterparts.

Further analysis of Group A and B mean scores reveal that on average Group B report more desirable beliefs than Group A (see Table 8). Considering that Group B respondents also indicate that they are exposed to more opportunity-to-learn, the data seems to suggest that an increase in opportunity-to-learn may result in an increase in B.Ed students' desirable beliefs (proportional relationship). Only beliefs about science achievement (BLF 3) violate this observation. Data further illustrates that content (CK) and pedagogical content (PCK) knowledge mean scores also violate this observation because there are no clear trends between the opportunity-to-learn and knowledge construct mean scores. In summary, the data seems to suggest that there are trends between opportunity-to-learn variables and B.Ed students' beliefs, but no trends (directly or inversely proportional) could be ascertained 
between opportunity-to-learn and knowledge mean scores. This is not to suggest that there are no possible associations between opportunity-to-learn variables' scores and knowledge scores, but it is to point out that this type of analysis does not reveal any possible associations between the constructs.

A closer look at Group B's beliefs and knowledge mean scores reveals an interesting phenomenon. Despite reporting statistically equivalent opportunity-to-learn, there are significant differences in the beliefs and knowledge mean scores of B.Ed students from U2 and U3. The post-hoc tests reveal that beliefs about the nature of science (BLF1), learning science (BLF2), and science achievement (BLF3) mean scores between the two universities are not statistically significantly equivalent (see Table 7). Furthermore, the same trend is observed in the knowledge construct. The post-hoc tests reveal that content (CK) and pedagogical content (PCK) knowledge mean scores for the two universities are not statistically significantly equivalent. The scores mentioned imply that B.Ed students' beliefs may be related to their knowledge and the converse may also be true that B.Ed students' knowledge may have an effect on their beliefs, as suggested by Mansour (2009). It is therefore possible that the interaction of knowledge and beliefs accounts for the variance observed in both knowledge and belief bundles constructs, while opportunity-to-learn is kept constant. The literature provides some guidance on this issue. Kutálková (2017) suggested that teachers' beliefs are shaped by their training and that beliefs act as a contextual filter that assists teachers in structuring their teaching experiences and, subsequently, in adapting their practices. Along the same line of thinking, Tondeur et al. (2016) suggested that beliefs act as a filter through which new knowledge is screened. Our study's findings, therefore, seem to support the stance that beliefs act as a filter for knowledge construction. The beliefs that serve as filters, according to the findings, are those about the nature of science (BLF1), learning science (BLF2), and science achievement (BLF3).

However, a closer look at Group A's mean scores reveals that U1 and U4 mean scores are statistically equivalent for all three constructs indicating that the trends in Group A are different from trends in Group B. The findings therefore suggest that the observation that beliefs act as a filter for knowledge cannot be regarded as conclusive and, rather, that the said link between knowledge and beliefs may exist only under certain conditions. The condition in the case of this study may be considered to be the significantly higher opportunity-to-learn that B.Ed students from group B were afforded.

\section{Conclusion}

Although this study has provided interesting results, there are limitations associated with the methodology we used.

Data was collected from final year pre-service physical science teachers who were registered for a B.Ed qualification and PGCE candidates were not considered. The knowledge test and opportunity-to-learn scale presented some limitations. Given the amount of time we had to administer the questionnaire, we could include only a limited number of items. Although we 
took care to cover reliably as many topics/opportunities-to-learn as possible, it was not possible to cover all the topics/opportunities-to-learn. Only four universities participated in the study so generalisation beyond the participating universities is not possible.

The findings from this study suggest that while the participating universities implement the same policy, their understanding of what makes a teacher education curriculum effective is based largely on the nature of the institution. Additionally, the findings suggest that there is a relationship between opportunity-to-learn and some B.Ed students' beliefs while no such relationship could be established between opportunity-to-learn and the knowledge constructs. The findings further support the notion that under certain conditions, beliefs may act as a contextual filter for knowledge construction.

The next phase of this investigation is to determine the specific opportunities-to-learn that explain the variance observed in the universities' knowledge and beliefs data.

\section{References}

Beauchamp, C. (2015). Reflection in teacher education: Issues emerging from a review of current literature. Reflective Practice, 16(1), 123-141.

Blomeke, S., \& Kaiser, G. (2014). Theoretical framework, study design and main results of TEDS-M. In S. Blomeke, F. J. Hsieh, G. Kaiser \& W. H. Schmidt (Eds.), International perspectives on teacher knowledge, beliefs and opportunities to learn (pp.19-47). Springer.

Blomeke, S., Suhl, U., Kaiser G., \& Döhrmann, M. (2012). Family background, entry selectivity and opportunities to learn: What matters in primary teacher education? An international comparison of fifteen countries. Teaching and Teacher Education, 28, $44-55$.

Boyd, D., Grossman, P., Hammerness, K., Lankford, H., Loeb, S., McDonald, M., Reininger, M., Ronfeldt, M., \& Wyckoff, J. (2009). Surveying the landscape of teacher education in New York City: Constrained variation and the challenge of innovation. Educational Evaluation and Policy Analysis, 30(4), 319-343.

Canrinus, E. T., Bergem, O. K., Klette, K., \& Hammerness, K. (2017). Coherent teacher education programmes: Taking a student perspective. Journal of Curriculum Studies, 49(3), 313-333.

Cetin, P. S., Dogan, N., \& Kutluca, A. Y. (2014). The quality of pre-service science teachers' argumentation: Influence of content knowledge. Journal of Science Teacher Education, 25, 309-331.

Council on Higher Education. (2010). Universities of Technology-Deepening the Debate. Kagisano No. 7. Jacana Media. 
Creswell, J. W. (2014). Research design: Qualitative, quantitative and mixed methods approaches. Sage.

Department of Higher Education and Training (DHET). (2015). Minimum requirements for teacher education qualifications. DHET.

Grossman, P., Hammerness, K. M., McDonald, M., \& Ronfeldt, M. (2008). Constructing coherence structural predictors of perceptions of coherence in NYC teacher education programs. Journal of Teacher Education, 59(4), 273-287.

Hancock, E. S., \& Gallard, A. J. (2004). Preservice science teachers' beliefs about teaching and learning: the influence of K-12 field experiences. Journal of Science Teacher Education, 15(4), 281-291.

Hoban, G. F. (2005). Developing a multi-linked conceptual framework for teacher education design. In G. F. Hoban (Ed.), The missing links in teacher education design (pp. 117). Springer.

Ingvarson, L., Beavis, A., \& Kleinhenz, E. (2007). Factors affecting the impact of teacher education programmes on teacher preparedness: Implications for accreditation policy. European Journal of Teacher Education, 30(4), 351-381.

Isdale, K., Reddy, V., Juan, A., \& Arends, F. (2017). TIMSS 2015 Grade 5 national report: Understanding mathematics achievement amongst Grade 5 learners in South Africa: Nurturing green shoots. Human Sciences Research Council Press.

Johnson, B., \& Christen, L. (2012). Educational research: Quantitative, quantitative and mixed approaches. Sage.

Koc, I. (2012). Preservice science teachers reflect on their practicum experiences. Educational Studies, 38(1), 31-38.

Kutálková, K. (2017). Beliefs of student of teaching: A case study. Procedia - Social and Behavioral Sciences, 237, 1160-1165.

Linacre, J. 2012. Winsteps (Version 4.0.0.0 [Computer Software]). http://www.winsteps.com/

Luckett, K. (2001). A proposal for an epistemically diverse curriculum for South African higher education in the 21 st Century. South African Journal of Higher Education, 15(2), 49-61.

Macugay, E. B., \& Bernardo, A. B. I. (2013). Science coursework and pedagogical beliefs of science teachers: The case of science teachers in the Philippines. Science Education International, 24(1), 63-77.

Mahlomaholo, S., Letsie, L., Tlali, M., Letloenyane, M., Mosia, M., Janqueira, K., du Toit, S., Papashane, M., Chele, T., \& Tshabalala, S. (2014). Teaching and learning 
deficiencies in physical science, mathematics and English in the North-West Dinaledi schools: A strategy for improvement. University of the Free State.

Mansour, N. (2009). Science teachers' beliefs and practices: Issues, implications and research agenda. International Journal of Environmental and Science Education, 4(1), 25-48.

Muller, J. (2009). Forms of knowledge and curriculum coherence. Journal of Education and Work, 22(3), 205-226.

Reddy, V., Visser, M., Winnaar, L., Arends, F., Juan, A., Prinsloo, C. H., \& Isdale, K. (2016). TIMSS 2015: Highlights of mathematics and science achievement of Grade 9 South African learners. Human Sciences Research Council Press.

Rogers, G. (2011). Learning-to-learn and learning-to-teach: The impact of disciplinary subject study on student-teachers' professional identity. Journal of Curriculum Studies, 43, 249-268.

Roychoudhury, A., \& Rice, D. (2013). Preservice secondary science teachers' teaching and reflections during a teacher education program. International Journal of Science Education, 35(13), 2198-2225.

Rusznyak, L. (2015). Knowledge selection in initial teacher education programmes and its implications for curricular coherence. Journal of Education, 60, 7-29.

Rusznyak, L., \& Bertram, C. (2014). An analysis of teaching practice assessment instruments: A cross-institutional case study of five universities in South Africa. JET Education Services.

Santau, A. O., Maerten-Rivera, J. L., Bovis, S., \& Orend, J. (2014). A mile wide or an inch deep? Improving elementary preservice teachers' science content knowledge within the context of a science methods course. Journal of Science Teacher Education, 25, 953-976.

Schmidt, W. H., Cogan, L., \& Houang, L. (2011). The role of opportunity to learn in teacher preparation: An international context. Journal of Teacher Education, 62(2), 138-153.

Shulman, L. S. (1986). Those who understand: Knowledge growth in teaching. Educational Researcher, 15(2), 4-14.

Spaull, N. (2013). South Africa's education crisis: The quality of education in South Africa 1994-2011. Centre for Development and Enterprise.

Tanase, M., \& Wang, J. (2010). Initial epistemological beliefs transformation in one teacher education classroom: Case study of four preservice teachers. Teacher and Teacher Education, 26, 1238-1248. 
Tatar, N. (2015). B.Ed students' beliefs about the image of a science teacher and science teaching. Journal of Baltic Science Education, 14(1), 34-44.

Tatto, M. T. (1996). Examining values and beliefs about teaching diverse students: Understanding the challenges for teacher education. Educational Evaluation and Policy Analysis, 18, 155-180.

Tatto, M. T., Schwille, J., Senk, S., Ingvarson, L., Peck, R., \& Rowley, G. (2008). Teacher education and development study in mathematics (TEDS-M): Policy, practice, and readiness to teach primary and secondary mathematics. Conceptual framework. Teacher Education and Development International Study Center, College of Education, Michigan State University.

Taylor, N. (2014). Initial teacher education research project: An examination of aspects of initial teacher education curricula at five higher education institutions. Summary Report. JET Education Services.

Tillotson, J. W., \& Young, M. J. (2013). The IMPPACT project: A model for studying how preservice program experiences influence science teachers' beliefs and practices. International Journal of Education in Mathematics, Science and Technology, 1(3), $148-161$.

Tondeur, J., van Braak, J., Ertmer, P. A., \& Ottenbreit-Leftwich, A. (2016). Understanding the relationship between teachers' pedagogical beliefs and technology use in education: A systematic review of qualitative evidence. Educational Technology Research and Development, 1-41. 